\title{
Islamic Tourism as a Factor of the Middle East Regional Development
}

\author{
Gordana Kovjanic* \\ Received: January 2014 | Accepted: February 2014
}

\begin{abstract}
For long time tourism, except pilgrimage travels, has been considered as culturally inappropriate and economically unnecessary phenomenon by Arab governments. At the beginning of $21^{\text {st }}$ century, many Arab states developed their tourism industries in order to diversify their economies (in the case of GCC states $=$ Gulf Cooperation Council) or to earn foreign currency (in the case of Arab Mediterranean states). Middle East importance for global stability derives from its immense oil reserves and its status as the epicentre of Muslim culture. The majority of their demand for tourism originates from neighbouring countries. The time of unrest in this part of the world has brought a need for local travellers to stay within the same cultural environment when making holiday destination choices.
\end{abstract}

Key words: Middle East, tourism development, Islam

\section{Introduction}

As a consequence of the global economic crisis, many tourists have turned to local or regional destinations for vacationing. This trend has been recognised all over the world, bringing new focus and more business to particular regions. Political crisis that happened before financial crisis were an important driver of regional tourism growth within the Middle East region. It caused the flourishing of so called Islamic tourism, with women only facilities and Sharia'h complain facilities for conservative Muslim demand. This paper will address these regional specifics, and emerging new trend of local tourism, as well as factors driving that trend, in order to explain their contribution to overall regional development.

\section{The Middle East and tourism features}

The Middle East as defined by the United Nations World Tourism Organisation (UNWTO) includes the following countries: Bahrain, Egypt, Iraq, Jordan, Kuwait, Lebanon, Libya, Oman, Palestine, Qatar, Saudi Arabia, Syria, UAE and Yemen. Israel belongs to the

\footnotetext{
* Abu Dhabi Vocational Education and Training Institute, Al Ain, UAE; gordana.kovjanic@adveti.ac.ae
} 
East-Mediterranean region of Europe. It is interesting that among these countries are those that have great natural and cultural attractions, as well as the potential for tourism, but for political, cultural and economic reasons this has not been exploited. In contrast there are those, especially the Arabian Gulf countries, which have managed to strengthen and diversify their economies towards the development of tourism thanks to their infrastructure and built attractions. Compared to other regions, the Arab world is an undeveloped market. For a long time tourism has been considered culturally undesirable, with the exception of pilgrimage, and economically unnecessary by Arab governments. There are powerful economic and political forces at play nationally and internationally and the outlook for tourism in the Middle East depends heavily on the degree of peace and security actually existing and believed to exist there. Since the very beginning of 2Ist century inbound extra-regional travellers have been discouraged by political instability and fears of global terrorism. On the other hand some Gulf nationals have been discouraged from travelling to America and Europe after the incidents of IIth September 2OOI.

Table 1. International tourism arrivals to Middle East between 1990-2011

\begin{tabular}{|c|c|c|c|c|c|c|c|c|c|c|c|c|}
\hline \multicolumn{9}{|c|}{ International tourist arrivals (in millions) } & \multirow{2}{*}{$\begin{array}{r}\begin{array}{r}\text { Market } \\
\text { share \% }\end{array} \\
2011\end{array}$} & \multicolumn{2}{|c|}{ Change \% } & \multirow{2}{*}{$\begin{array}{l}\begin{array}{c}\text { Average annu- } \\
\text { al growth \% }\end{array} \\
05-11\end{array}$} \\
\hline 1990 & 1995 & 2000 & 2005 & 2007 & 2008 & 2009 & 2010 & 2011 & & $10 / 09$ & $11 / 10$ & \\
\hline 9,6 & 13,7 & 24,9 & 37,8 & 46,7 & 55,6 & 52,8 & 60,3 & 55,4 & 5,6 & 14,2 & -8 & 7,3 \\
\hline
\end{tabular}

Source: UNWTO, 2012 (data collected by June 2012)

According to the UNWTO Middle East had one of the highest growth rates of international tourist arrivals between 2005 - 2OII, increasing on average by $7.3 \%$ per year (Table I). The number of international tourist arrivals in 2009 for the first time in the last twenty years has declined by almost $5 \%$ compared to year 2008. In 2010 the highest growth rate in the world was recorded, reaching I4.2\%, but in the following year the Middle East and North Africa were the only regions where tourist arrivals declined. The region lost an expected 5 million international arrivals in 2OII and numbers declined by $8 \%$ due to the "Arab Spring." Most Middle Eastern destinations felt the direct or indirect consequences of socio-political unrest and change in the region. The biggest decreases were recorded by Syria -4I\%; Egypt -32\%; Lebanon -24\%; Palestine I5\%; and Jordan -I3\%. In contrast, some destinations recorded a significant increase in international tourist arrivals in 2OII such as Dubai, which recorded a growth of $9 \%$ over the same period (UNWTO, 2OI2). Also very impressive is the case of Saudi Arabia, with a growth rate of $60 \%$, which reflects the changing attitude of Saudi authorities towards tourism and its role in the national economy. At the UNWTO Ministerial Conference held in May 2013 in Dubai, Prince Sultan bin Salman bin Abdul Aziz - President of SCTA (Saudi Commission for Tourism and Antiquities) announced the expansion of Jeddah airport and the development of conference centres, noting that although the KSA entered the tourism market just three years ago, it has very ambitious plans. The latest UNWTO data shows that the Middle East has achieved 52 million tourist arrivals in $2 \mathrm{OI} 2$, as a (5\%) of the total international tourist arrivals worldwide.

Another indicator - international tourism receipts, shows that in 2012 the Middle East generated 47 billion dollars, which means $4 \%$ share of the total revenues generated in international tourism (UNWTO, 2OI3).

Positive growth was recorded in all regions of the world in 2OI2, except the Middle East, where the number of tourist arrivals fell by 3 million as compared to the previous year 


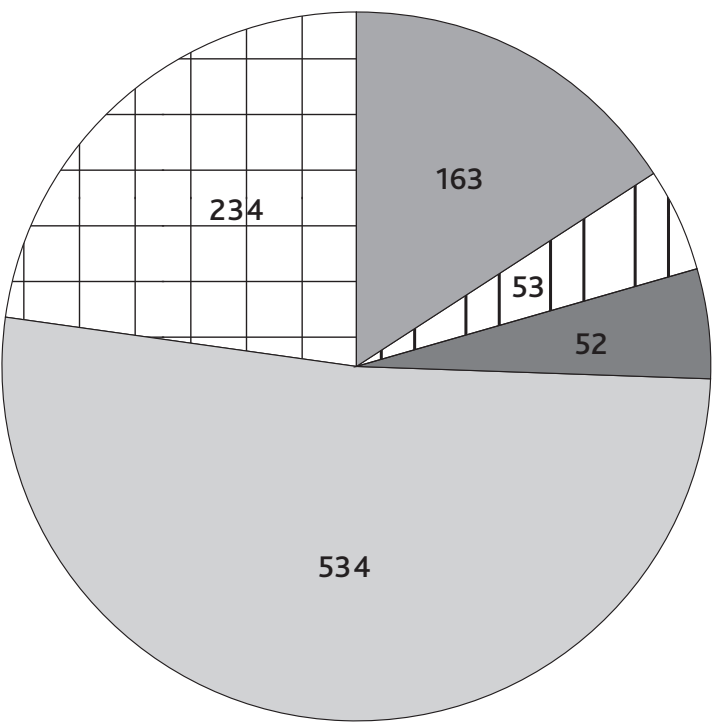

Americas, $16 \%$ Africa, $5 \%$

Middle East, 5\%

Europe, 52\% Asia and the Pacific, 23\%

Figure 1. International Tourist Arrivals (millions), 2012 Source: World Tourism Organization (UNWTO)

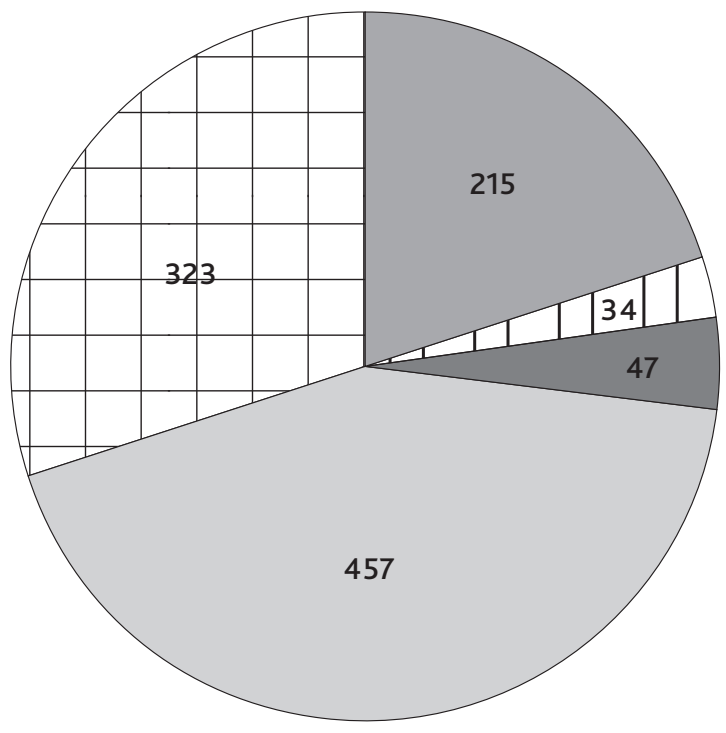

Americas, $20 \%$ Africa, 3\%

Middle East, 4\% Europe, 43\% Asia and the Pacific, 30\%

Figure 2. International Tourism Receipts (US\$ billion), 2012 Source: World Tourism Organization (UNWTO)

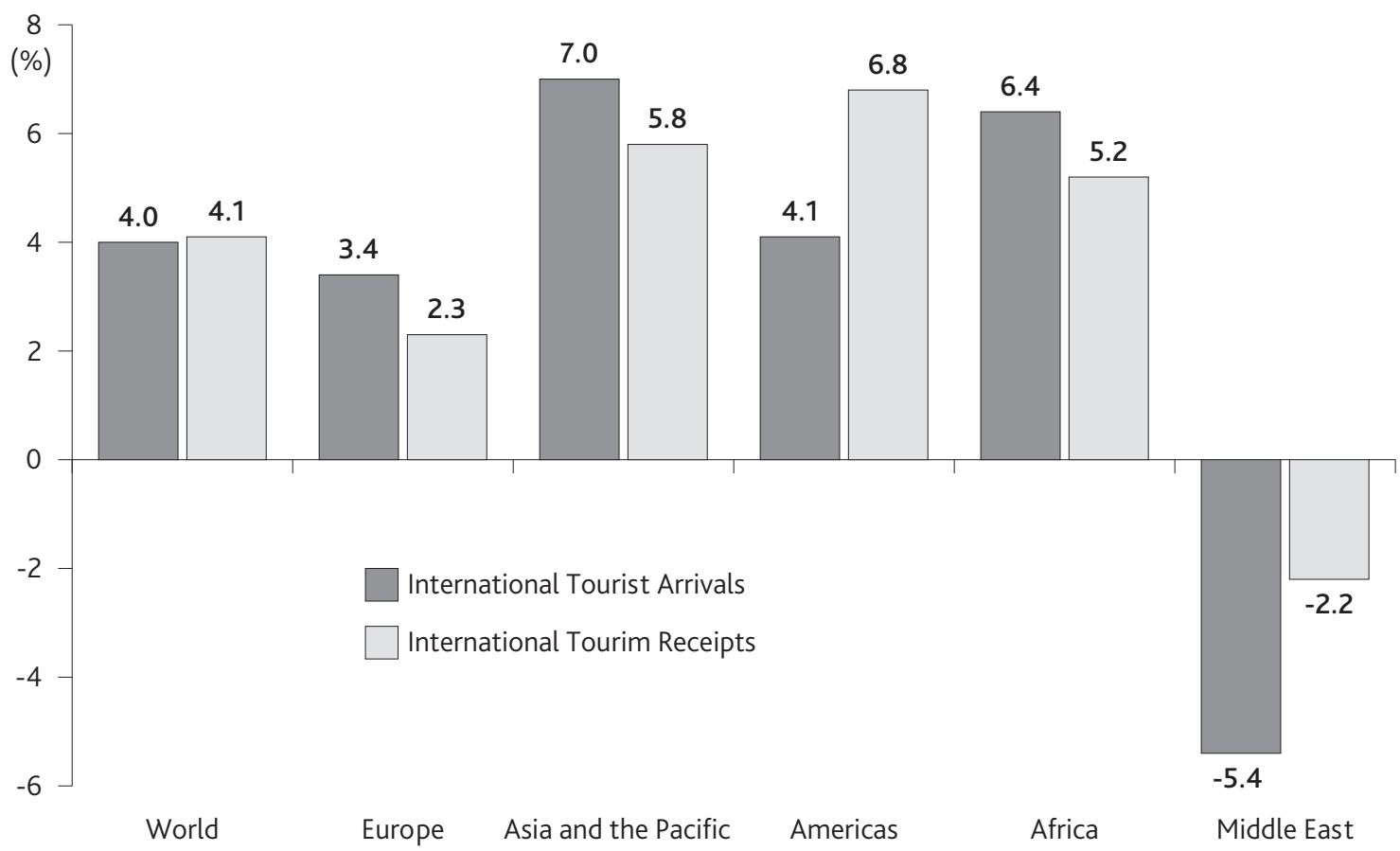

Figure 3. Change in International tourist arrivals and receipts (local currencies, constant prices) - \% change 2012/2011 Source: World Tourism Organization (UNWTO) 
(UNWTO, 2OI3). This region saw $2 \%$ drop due to the continuing political turbulence in the region; yet saw a gradual improvement compared to the decline in $2 \mathrm{OII}$ (-I4\%).

\section{The key factors of flourishing of regional tourism}

There are several reasons why tourism within the region is flourishing. Some belong to the so-called "push" factors that discourage Arabs from their traditionally favourite destinations in the USA and Europe, where they have difficulties to obtaining visa (especially USA). On the other side, the "pull" factors that are attracting Arab tourists to regional destinations include an improved tourist infrastructure - new hotels, theme parks, resort projects, shopping centres, and general infrastructure - modern roads and airports to facilitate mobility within the region, but also enhanced promotion. Even Saudi Arabia has introduced new "Umrah-plus" arrangements that combine pilgrimage trip to Mecca and Madinah with tourism and recreation in other cities of the kingdom. This trend has become established in the last few years by the fact that Ramadan - the Islamic month of fasting has fallen in summer (the high tourist season), which encourages a large number of faithful travellers to stay at home or within the region. Improved tourist products, investments in tourism promotion, as well as overall socio-cultural environment are appealing to regional tourists.

The intra-regional tourism flourished after 09/II/2OOI as never before, because the residents, fearful of the consequences of the September attacks, cultural tensions, misunderstandings and Islamophobia, turned to regional holidays. During 2002, the Middle East recorded the highest growth rate in tourist arrivals in the world $16.7 \%$, while revenues increased by IO\% compared to the previous year (WTO, 2OO3). At the same time, the participation of Arab tourists in overall tourist arrivals in the USA and Europe has declined by 50\% and 30\% respectively (World Tourism Global Trends Reports, 2009). Unrest in Middle Eastern and North African countries continue to influence the regional tourism industry. During 2OII the Middle East attracted headlines around the world because of events related to the "Arab Spring". That caused many overseas tourists to stay out of the region, even away from countries that have not experienced social unrest. Because of the potential problems now faced in opting to holiday in the west, many Muslims prefer to stay within the same culture when choosing vacation destinations. Arab tourists, especially those from the Gulf, are well known as high spending consumers. They are not much interested in visiting cultural and historical sites, but prefer destinations that offer fun, shopping, family activities, and above all relaxation. Arab tourists are repeat customers that tend to revisit regularly if they like the place. Persian Gulf countries have become a major tourist source market for other Muslim countries like Malaysia, Indonesia, Lebanon, Turkey, UAE, Bahrain, and Egypt. Specific needs and expectations of Muslim tourists who choose to stay within their cultural environment, caused the emergence of a new segment of the tourism market called Islamic tourism. It is defined as tourism undertaken by Muslims or more widely understood as including non-Muslims traveling to the Muslim world (Al-Hamarneh, 2008) and (Zamani-Farahani \& Henderson, 2009). According to Al-Hamarneh, Islamic tourism can be seen as a cultural and religious concept, which aims to revive the Islamic and Arab culture and develop cultural self-confidence (Al-Hamarneh, 2008). This approach goes beyond fundamental perception that Islamic tourism is solely about pilgrimage, stressing the broader concept which doesn't necessarly have to, but can include religiosity (Al-Hamarneh \& Steiner, 20O4). The trend of accelerated expansion of this type of tourism and the emergence of a 
distinct market segment with growth potential, was highlighted by the report of one of the world's largest tourism trade shows, the London World Travel Market (WTM report 2007).

\section{The Islamic conception of tourism}

Religion is an important factor that can help shape the culture, attitudes and values of society. Based on the Islamic understanding of God, man and nature, tourism is a part of religion, and travel is fundamental in Islam (Hasharina, 2006). Travel is encouraged in order to lead a healthy life without stress, to establish and strengthen links across the Muslim community - Ummah (مأم), to expand knowledge of other cultures, and to "reinforce subordination of the individual to God through the knowledge of the beauty and abundance of his creations" (Hasharina, 2006).

Contrary to popular public opinion, Islam accepts and encourages tourism. There are I6 verses in the Qur'aan that directly encourage Muslims to travel. Muslims are taught to talk to God as fully as possible since through one's personal experience of the world one can understand the greatness of God and smallness of man. Travel results in the acquisition of knowledge and tests the patience and the perseverance in the individual (Zamani-Farahani, 2OIO). Muslim countries tend to interpret what the Qur'aan says about tourism. There are various forms of travel:

- Hijja (zج) involves travel and pilgrimage to Mecca, which is requirement for every healthy adult Muslim, at least once in lifetime, to take the Hajj, unless physically unabled.

- Zejara (مرايز) refers to visit to other holy places.

- Rihla (Jق) is a trip for other reasons, such as education and trade. The emphasis is on purposeful movement, as a component of the spiritual journey in the service of God.

Shari'ah (نعيرشل) law determines what is acceptable - halal (لالح)), and what is unacceptable - haram (حارح) in everyday life and during travel. The law prohibits the public outpouring of emotion, any type of physical contact between persons of the opposite sex, unmarried couples staying in the same hotel room, gambling, breaking of the Ramadan fast during the day, eating pork and other forbidden foods, alcohol and indecent clothing. It is possible to postpone Ramadan regular prayer and fasting while traveling. Visiting bars, night clubs and similar entertainment is against the law. Gender segregation means that men and women are separated in institutions and during public events. Compliance with these rules and constraints in their implementation vary in different Islamic countries. In some countries, religious principles are strictly adhered to, (in KSA there is even a religious police) while others are more relaxed (Zamani-Farahani \& Henderson, 2009). While tourism in Saudi Arabia and Iran, as the two most important religious destinations for the Hajj and Shia pilgrimage (tombs of the Imams and their immediate followers and close associates are holy places for Shia Muslims) has religious-conservative characteristics, other countries such as the UAE, Malaysia, Turkey, are cosmopolitan, relatively liberal, shopping and recreation-oriented destinations (Zamani-Farahani \& Henderson, 2OIO).

For Muslim religious conceptions, tourists visiting important religious places motivated by different interests may be unacceptable. The lack of sensitivity on the part of tourists can have undermining effects on sacred sites and non-Muslim tourists may disturb local residents by ignoring or deliberately behaving contrary to the rules that dictate the daily lives of 
Muslims. Tourism is often associated with behavior unacceptable to Islamic values and cultural traditions (Zamani-Farahani \& Henderson, 2009), and some communities prefer to avoid non-Muslim tourists. Dissatisfaction with westernization and declining moral standards are sometimes perceived as inevitable companions of tourism (Ap et al, I99I), but that has a wider application and is not limited to the followers of Islam only.

\section{Islamic tourism}

Islamic tourism and Halal hospitality which is akin to the concept of Halal food (Battour et al., 2OII), flourish in the Persian Gulf, especialy in GCC countries known for their conservative interpretation of Islamic Sharia'h law. Sharia'h-compliant hotels have traditionally existed in such countries as Saudi Arabia and Kuwait. Moreover, Sharia'h-compliance is not a matter of choice for either hotel operators or guests in places like KSA and Iran. These hotels contain such features as traditional uniforms for hotel staff, dress code for female staff, even for guests, markers indicating the direction of Mecca (Mecca stickers or Qibla stickers = stickers with ornamented arrows pointing towards the city of Mecca in Saudi Arabia for prayer directions), female and male prayer rooms, prayer mats and prayer beds - tasbi, halal food with no pork, conservative television channels, art that does not depict the human form, and beds and plumbing placed away from facing Mecca. Furthermore, finance used to operate the hotel should be compliant to Sharia'h regulations and the hotel owner must contribute a proportion of revenue to Zakat (charitable acts), (Stephenson et al., 2OIO). As Mus-

Table 2. UAE Inbound Tourism, 2010-2017

\begin{tabular}{|c|c|c|c|c|c|c|c|c|}
\hline \multicolumn{9}{|c|}{ UAE Inbound Tourism, 2010-2017 } \\
\hline & 2010 & 2011 & $2012 \mathrm{e}$ & $2013 f$ & $2014 f$ & $2015 f$ & $2016 f$ & $2017 f$ \\
\hline Total Arrivals, '000 & $9,123.55$ & $10,005.13$ & $10,855.56$ & $11,941.12$ & $12,932.23$ & $13,915.08$ & $14,930.88$ & $15,976.05$ \\
\hline $\begin{array}{l}\text { Total Arrivals, } \\
\% \text { change y-o-y }\end{array}$ & 9.38 & 9.66 & 8.50 & 10.00 & 8.30 & 7.60 & 7.30 & 7.00 \\
\hline \multicolumn{9}{|l|}{ Inbound arrivals by region } \\
\hline Africa, '000 & 252.97 & 279.24 & 322.59 & 383.68 & 443.66 & 494.64 & 544.64 & 607.06 \\
\hline Africa, \% change y-o-y & 4.06 & 10.38 & 15.52 & 18.94 & 15.63 & 11.49 & 10.11 & 11.46 \\
\hline North America, '000 & 599.36 & 587.29 & 778.07 & 891.71 & 985.65 & $1,077.10$ & $1,164.29$ & $1,262.04$ \\
\hline $\begin{array}{l}\text { North America, } \\
\% \text { change y-o-y }\end{array}$ & 8.26 & -2.01 & 32.48 & 14.61 & 10.53 & 9.28 & 8.10 & 8.40 \\
\hline Latin America, '000 & 6.96 & 8.09 & 7.54 & 9.73 & 11.69 & 13.39 & 15.60 & 17.40 \\
\hline $\begin{array}{l}\text { Latin America, } \\
\% \text { change } y-0-y\end{array}$ & 22.33 & 16.33 & -6.88 & 29.09 & 20.19 & 14.53 & 16.52 & 11.50 \\
\hline Asia Pacific, '000 & $1,838.71$ & $2,047.47$ & $2,328.10$ & $2,603.12$ & $2,893.51$ & $3,224.25$ & $3,571.97$ & $3,935.18$ \\
\hline $\begin{array}{l}\text { Asia Pacific, } \\
\% \text { change y-o-y }\end{array}$ & 12.64 & 11.35 & 13.71 & 11.81 & 11.16 & 11.43 & 10.78 & 10.17 \\
\hline Europe, '000 & $2,305.63$ & $2,304.14$ & $2,397.46$ & $2,535.18$ & $2,716.16$ & $2,894.37$ & $3,101.50$ & $3,266.67$ \\
\hline Europe, \% change y-o-y & 4.55 & -0.06 & 4.05 & 5.74 & 7.14 & 6.56 & 7.16 & 5.33 \\
\hline Middle East, '000 & $2,208.51$ & $2,743.95$ & $2,813.89$ & $3,016.01$ & $3,172.23$ & $3,296.10$ & $3,404.82$ & $3,540.68$ \\
\hline $\begin{array}{l}\text { Middle East, } \\
\% \text { change y-o-y }\end{array}$ & 15.01 & 24.24 & 2.55 & 7.18 & 5.18 & 3.91 & 3.30 & 3.99 \\
\hline
\end{tabular}

e/f=BMl estimate/forecast. Source: Dubai Tourism, Abu Dhabi Tourism, BMI 
lims avoid free mixing between the sexes, hotels should offer separate swimming pools and recreational facilities (Henderson, 2003) and all female floors. Allocating female staff for women and male staff for men, such as availability of taxis with female driver services for female passengers satisfies the needs of some Middle Eastern families. Women-only hotels are opening up across the region as culturally acceptable and tailored concepts for growing young female population. The negative side of western tourism causing Islamic tourism to be increasingly popular among some conservative Muslims are issues that have a negative impact on the Muslim community such as the consumption of alcohol, prostitution, inappropriate dressing, kissing in public and open affection between sexes in public.

Most of GCC countries are known as high earning gas and oil exporters. They advocate luxury tourism as they have a rich, young population, with high expectations in terms of quality and services offered. High spending power and comparatively long length of stay, as well as a tendency to travel in large family parties are the reasons why GCC travellers are very much welcomed. As an example of Islamic tourism expansion within the region, UAE tourism statistics with tourist inbound and outbound flow, will be presented. Compared to other world regions, the highest number of UAE visitors come from within the region. This number was growing rapidly over the past several years, confirming the regional trend. At the same time the highest percentage of travellers from UAE visit regional destinations. The same trend is forecasted to continue until 2017 by BMI, as shown in Table 2 and Table 3 (BMI, 2OI3).

Table 3. UAE Outbound Tourism, 2010-2017

\begin{tabular}{|c|c|c|c|c|c|c|c|c|}
\hline \multicolumn{9}{|c|}{ UAE Outbound Tourism, 2010-2017 } \\
\hline & 2010 & 2011 & $2012 \mathrm{e}$ & $2013 f$ & $2014 f$ & $2015 f$ & $2016 f$ & $2017 f$ \\
\hline $\begin{array}{l}\text { Total Outbound, tourist depar- } \\
\text { tures, '000 }\end{array}$ & $3,182.63$ & $2,831.40$ & $2,923.85$ & $3,188.47$ & $3,487.79$ & $3,838.62$ & $4,204.37$ & $4,599.76$ \\
\hline $\begin{array}{l}\text { Total Outbound, tourist depar- } \\
\text { tures, \% change y-o-y }\end{array}$ & 6.14 & -11.04 & 3.26 & 9.05 & 9.39 & 10.06 & 9.53 & 9.40 \\
\hline $\begin{array}{l}\text { Average Tourist Departure per } \\
1000 \text { of the population }\end{array}$ & 0.42 & 0.36 & 0.36 & 0.39 & 0.42 & 0.46 & 0.49 & 0.53 \\
\hline \multicolumn{9}{|c|}{ Outbound, resident departures by destination } \\
\hline Africa, '000 & 251.08 & 253.69 & 250.38 & 264.16 & 280.52 & 300.93 & 320.98 & 344.13 \\
\hline Africa, \% change y-o-y & 15.02 & 1.04 & -1.30 & 5.50 & 6.19 & 7.28 & 6.66 & 7.21 \\
\hline North America, '000 & 16.89 & 20.45 & 21.40 & 23.14 & 25.24 & 27.76 & 30.41 & 33.22 \\
\hline North America, \% change y-o-y & 27.39 & 21.10 & 4.65 & 8.11 & 9.07 & 10.01 & 9.52 & 9.26 \\
\hline Latin America, '000 & 0.26 & 0.22 & 0.13 & 0.13 & 0.13 & 0.12 & 0.11 & 0.11 \\
\hline Latin America, \% change y-o-y & 176.34 & -13.62 & -40.54 & 0.76 & -1.50 & -10.69 & -3.42 & -2.65 \\
\hline Asia Pacific, '000 & 325.19 & 324.79 & 343.14 & 365.54 & 395.65 & 426.64 & 457.30 & 490.07 \\
\hline Asia Pacific, \% change y-o-y & 12.79 & -0.12 & 5.65 & 6.53 & 8.24 & 7.83 & 7.19 & 7.17 \\
\hline Europe, '000 & 256.06 & 344.87 & 312.21 & 344.08 & 366.76 & 386.53 & 405.59 & 429.46 \\
\hline Europe, \% change y-o-y & -9.65 & 34.68 & -9.47 & 10.21 & 6.59 & 5.39 & 4.93 & 5.88 \\
\hline Middle East, '000 & $2,333.15$ & $1,887.38$ & $1,996.57$ & $2,191.41$ & $2,419.50$ & $2,696.64$ & $2,989.98$ & $3,302.77$ \\
\hline Middle East, \% change y-o-y & 6.29 & -19.11 & 5.79 & 9.76 & 10.41 & 11.45 & 10.88 & 10.46 \\
\hline
\end{tabular}

e/f=BMl estimate/forecast. Source: National Sources, BMI 


\section{Muslim governments and prospects for tourism development in the Middle East}

Although they share the same religious beliefs, Islamic nations are not homogeneous in their views. The situation varies from country to country and depends on the official interpretation of Islam and local culture, the role of local communities in society, the degree of liberalism and state interventionism (Zamani-Farahani \& Musa, 2OII). Popular Mediterranean destinations such as Egypt, Morocco and Turkey are willing to accommodate the demands of tourists regardless of the differences because of the economic benefits. Political ideology combined with a wish to avoid social unrest has caused some Middle Eastern countries to discourage tourists from the West, believing that Western forms of tourism are not consistent with Islam (Iran, KSA, Brunei). In the last few years, the isolationist Kingdom of Saudi Arabia has tried to develop international tourism (tourist arrivals increased in 20II by 6I\%) in order to diversify the economy. Segregation of tourists and residents is the strategy applied by the government in the Maldives. Some of the many small islands are selected and maintained solely for the use of tourists, and access to other inhabited islands is government-regulated. Such a policy is possible due to specific geographical location of the country. Developing integrated beach resorts in some Red Sea coastal destinations, so called Enclave tourism, is an approach that is also based on the separation of the local community and tourists, with both sides occupying clearly defined, separate spaces, with minimal possibility of interaction. This creates dissatisfaction among a number of Western tourists who want to gain an impression of the local culture and people. The recent movement of GCC countries toward the rapid development of service sector industries has been strongly encouraged by national and international investments, and market liberalisation (Stephenson et al., 2OIO). A range of "pro-tourism" policies served to improve tourism growth in Dubai (Sharpley, 2008) helping it to establish its status of one of the world top destinations.

In the first part of 2013 the regions of Asia and the Pacific and the Middle East saw the highest growth, both recording a $5 \%$ increase in the arrivals (UNWTO, 2OI3). In the same period international passenger demand rose around the world, where the best performing regions were the Middle East and Latin America showing the growth of I4\% and IO\% respectively. Statistics compiled by the Arab Air Carriers Organization showed an impressive II.7\% rise in passenger traffic in $20 \mathrm{OI}$ - by far the strongest growth of all regions' airlines worldwide (UNWTO, 2OI3). Hospitality industry in MENA region in same period achieved growth showing that average occupancy rose by $3.5 \%$ up to $60.3 \%$. The region remained popular with developers and guests growing 6\% in room inventory and IO\% in demand. It is expected that MENA region will attract the strongest growth II\% by the end of 2OI4, assuming all hotels under construction or planned come on line as scheduled. The Middle East/Africa hotel development pipeline comprises 483 hotels totalling II8,7I3 rooms (UNWTO, 20I3). To complete the regional picture, one can add rapid growth of regional low cost carriers FlyDubai and Air Arabia, and opening of new Al Maktoum airport in Dubai (just partly opened for commercial flights). Abu Dhabi hosts a Formula One grand prix and is building the largest museum complex in the world (Saadiyat Cultural District with Louvre and Gugenheim in focus). Qatar became famous after winning the 2022 Soccer World Cup bid and is also building hotel capacity. Dubai is positioned as a hub for the Middle East, and after winning the $202 \mathrm{O}$ World Expo bid has further established itself as unique regional destination. Tourism prospects within the region are promising. 


\section{Conclusion}

Arab countries of the Middle East share a similar culture, values, language and belief. Religion shapes the culture, attitudes and values of society. Islam is the main link between the people of the region - it is not merely a religion, it is a way of life. The place and influence of religion is particularly emphasized, because without knowledge and understanding of Islam, which defines all the events in both the private and business life, many things in this part of the Muslim world would remain unclear.

Global market trends caused by the rise of terrorism around the world, the global financial crisis and decline in tourists source markets have affected the global tourism industry dramatically, but have pushed up intraregional tourism within the MENA region. Unexpectedly, tourism has flourished within the region. This has given rise to the emergence of a new segment of the tourism market called Islamic tourism. It was developed as an answer to the needs of local Muslim populations keen to stay within their cultural and religious environment while on vacation. The biggest growth in tourist arrivals within the region has contrasted with global decline, highlighting a spontaneous local reaction which was turned into a prioritisation policy later on. Regionalism vs globalism, based on socio-cultural similarities and empathy. Nowadays, the situation is changing due to constant political turbulence in the region. It is recording a slump while the rest of the world records growth. Despite the numerous challenges being faced, the Middle East is one of the fastest growing tourism regions of the world. Clear political will and commitment to tourism in the region, as well as the vision that tourism is one of the main pillars of the development of the region, contributes to this dynamic (Rifai, 20I3).

\section{References}

Al-Omar, A. R. B. H. (I99I). The Religion of Truth Riyadh, KSA I4I2 A.H.-I99I A.D

Al-Hamarneh A. \& Steiner C. (2004). Comparative Studies of South Asia, Africa and the Middle East 24, I, I73-I82.

Ap J., Var T., \& Din K. (I99I). Malaysian perceptions of tourism. Annals of Tourism Research, I8, 2, 32I-323.

Battour M., Nazari I. M. \& Battor M. (2OII). The Impact of Destination Attributes on Muslim Tourist's Choice, International Journal of tourism research, I3, 527-54O.

Business Monitor International, BMI (2OI3). UAE Tourism Report Q3 2013.

Chaaban J. (2OIO). Job Creation in the Arab Economies: Navigating Through Difficult Waters, United Nations Development Programme, Regional Bureau for Arab States, Arab Human Development Report, Research Paper Series 2010.

Coury T. \& Chetan D. (2009). Oil, Labor Markets, and Economic Diversification in the GCC: An Empirical Assessment, The Dubai Initiative, Working Paper Belfer Center for Science and International Affairs, Harvard Kennedy School

Daher R. (2007). Tourism in the Middle East: Continuity, Change, and Transformation, Tourism and Cultural Change, 9.

Din, K.H. (I989). Islam and tourism: patterns, issues and options, Annals of Tourism Research, I6, 542-63.

Donboli J. H. \& Kashefi F. (2005). Doing Business in the Middle East: A Primer for U. S. Companies, Cornell International Law Journal, 38. 
Erslev, A. L. (2OI2). The Regional Security Complex of the Persian Gulf: Bahrain in a new global power balance after the Arab Spring, Athens: ATINER'S Conference Paper Series, No: MDT2OI2-OOO4.

Euromonitor International (2OI3). WTM vision 2OI3: Forecast Revisit for the Global Travel and Tourism Industry, Dubai, report for 07/05/2013.

Fattouh, B. \& El-Katiri, L. (2OI2). Energy and Arab Economic Development, United Nations Development Programme, Regional Bureau for Arab States, Arab Human Development Report, Research Paper Series 2012.

Henderson, J. C. (2003). Managing tourism and Islam in Peninsular Malaysia, Tourism Management, 24, 447-456.

Henderson, J. C., (2OIO). Sharia-compliant hotels, Tourism and Hospitality Research, IO, 3, 246-254.

Henderson, J.C. (2OII). Religious Tourism and Its Management: The Hajj in Saudi Arabia, International Journal of Tourism Research, I3, 54I-552.

Kalesar, M. I. (2OIO). Developing Arab Islamic Tourism in the Middle East: An Economic Benefit or A Cultural Seclusion? International Politics, 3, 5.

Mirki, B. (20I3). Arab Spring: Demographics in a region in transition, United Nations Development Programme, Regional Bureau for Arab States, Arab Human Development Report, Research Paper Series 2013.

Saidi, N., Scacciavillani, F. \& Fahad, A. (2OIO). Forecasting Tourism in Dubai, Economic Note No. 8, DIFIC.

Sharpley, R. (2008). Planning for tourism: the case of Dubai, Tourism and Hospitality Planning and Development, 5, I, I3-30.

Sharpley, R. (2OO2). The Challenges of Economic Diversification through Tourism: the Case of Abu Dhabi, International Journal of Tourism Research 4, 22I-235.

Rifai, T. (20I3). UNWTO Secretary-General Speach, UNWTO Ministerial Forum in Dubai, May, $2 \mathrm{OI} 3$.

Stephenson, M. L., Russell, K. A. \& Edgar, D. (2OIO). Islamic hospitality in the UAE: indigenization of products and human capital, Journal of Islamic Marketing, I, I, 9-24.

UNWTO (2OI3). World Tourism Barometer, Vol. II, April. Retrieved from http://dtxtq4w6oxqpw.cloudfront.net/sites/all/files/pdf/unwto_baromI3_O2_apr_excerpt_o.pdf, downloaded July, $2 \mathrm{OI} 3$.

UNWTO (20I3). Tourism Highlights. Retrieved from http://dtxtq4w6oxqpw.cloudfront. net/sites/all/files/pdf/unwto_highlightsi3_en_hr.pdf, downloaded Feb. I4, 2014.

UNWTO (2OI2). Tourism Highlights. Retrieved from http://mkt.unwto.org/sites/all/files/ docpdf/unwtohighlightsizenhr.pdf, downloaded Feb. I4, $2 \mathrm{OI} 4$.

UNWTO (2OII). Tourism trends, Assessment and a Glimpse of UNWTO Retrieved from http://dtxtq4w6oxqpw.cloudfront.net/sites/all/files/pdf/presentation_I_sep_by_unwto. pdf , downloaded Feb.I4, 2014

UNDP (2OI3). Human Development Report 20I3, The Rise of the South: Human Progress in a Diverse World. Retrieved from http://hdr.undp.org/sites/default/files/reports/I4/ hdr2OI3_en_complete.pdf, Feb. I4, 2OI4

United Nations Population Division, Department of Economic and Social Affairs, World population Prospects: The $2 \mathrm{OI} 2$ Revision. Retrieved from http://www.unfpa.org/webdav/site/global/shared/documents/news/2OI3/KEY\%2OFINDINGS\%2OWPP2OI2_ FINAL-2.pdf , Feb. I4, 2014 
Urdal, H. (20I2). A Clash of Generations? Youth Bulges and Political Violence, United Nations Population Division, Expert Paper No. 2OI2/I. Retrieved from http://www.arabhdr.org/publications/other/ahdrps/AHDR\%2OENG\%2OArab\%2OSpring\%2OMirkinv3. pdf , Feb. I4, 2014

Zamani-Farahani, H. \& Musa G. (2008). Residents' Attitudes and Perception towards Tourism Development: A Case Study of Masooleh, Iran, Tourism Management, 29, 6, I233I236.

Zamani-Farahani, H. (2OIO). Tourism and Pilgrimage among OIC Member Countries, Economic \& Trade Integration among OIC Member Countries: Opportunities and Challenges $2^{\text {nd }}$ International Conference, November 2I-22, 2OIO, Iran-Tehran

Zamani-Farahani, H. \& Henderson, J. C. (2OIO). Islamic Tourism and Managing Tourism Development in Islamic Societies: The Cases of Iran and Saudi Arabia, International Journal of Tourism Research, I2, 79-89.

Zamani-Farahani, H. \& Musa, G. (2OII). The relationship between Islamic religiosity and residents' perceptions of socio-cultural impacts of tourism in Iran: Case studies of Sare'in and Masooleh, Tourism Management 33, 802-8I4.

WTM (2007). The World Travel Market Global Trend Reports 2007, World Travel Market: London. Retrieved from https://www.google.ae/search?q=unwto+tourism+highlights+2OI2+edition+pdf\&rlz=ICITEUA_enAE468AE468\&oq=UNWTO+(2OI2).+Tourism+Highlights\&aqs=chrome.3.69i57 jol3.I85O3joj8\&sourceid $=$ chrome\&espv $=2$ IO\&es_sm=93\&ie $=U T F-8 \# q=W T-$ $\mathrm{M}+(2007)+$ +The+World+Travel+Market+Global+Trend+Reports $+2007 \% 2 \mathrm{C}+$ World+Travel+Market $\% 3 \mathrm{~A}+$ London. Feb. I4, 2014 